Research Article

\title{
Contact Toxicity Effects of Selected Organic Leaf Extracts of Tithonia diversifolia (Hemsl.) A. Gray and Vernonia lasiopus (O. Hoffman) against Sitophilus zeamais Motschulsky (Coleoptera: Curculionidae)
}

\author{
Stephen Maina Gitahi $\left(\mathbb{D},{ }^{1}\right.$ Mathew Piero Ngugi $\mathbb{D}^{1},{ }^{1}$ David Nganga Mburu $\mathbb{D}$, \\ and Alex Kingori Machocho ${ }^{2}$ \\ ${ }^{1}$ Department of Biochemistry, Microbiology and Biotechnology, Kenyatta University, P. O Box 43844-00100, Nairobi, Kenya \\ ${ }^{2}$ Department of Chemistry, Kenyatta University, P. O Box 43844-00100, Nairobi, Kenya
}

Correspondence should be addressed to Stephen Maina Gitahi; gitahism@gmail.com

Received 21 October 2020; Revised 22 February 2021; Accepted 4 September 2021; Published 16 September 2021

Academic Editor: Edson Gandiwa

Copyright (C) 2021 Stephen Maina Gitahi et al. This is an open access article distributed under the Creative Commons Attribution License, which permits unrestricted use, distribution, and reproduction in any medium, provided the original work is properly cited.

\begin{abstract}
Maize weevil (Sitophilus zeamais) infestation results in a substantial reduction in the quantity and deterioration of the quality of stored maize. Most farmers control weevils using conventional pesticides which are usually associated with several human health risks as well as intoxication of the fauna and flora. However, bioinsecticides form an alternative intervention since they possess fewer side effects on human health, are ecofriendly, and are readily available. This study sought to validate and document, in a systematic way, the pesticidal properties of the species Tithonia diversifolia and Vernonia lasiopus used for many years by many people of the world on S. zeamais. The plant leaf samples were obtained from Embu County, Kenya. Dichloromethane and ethyl acetate solvents were used to extract active phytochemicals from the dried plant sample powder. The GC-MS analysis of the obtained extracts was performed at ICIPE laboratories to identify their phytochemical compositions. Twenty grams of maize grains were put in $50 \mathrm{ml}$ plastic vials and admixed with different treatments. The positive control group was treated with Actellic Super $^{\mathrm{TM}}$, while the negative control was treated with the respective extracting solvent only. The experimental groups were separately treated with the plant leaf extracts at doses of 25,50,75, and 100\%. After treatment, each of the six groups was infested with 10 male $S$. zeamais and weevil mortality as a result of contact toxicity of the treatments was assessed at $6,24,48,72$, and 96 hours after the insects were exposed to the extracts. Results of the study indicate that the selected organic leaf extracts of $T$. diversifolia and $V$. lasiopus possessed significant contact insecticidal effects that ranged between 1.67 to $99.98 \%$. Furthermore, the GC-MS analysis revealed several active biocompounds in T. diversifolia and V. lasiopus extracts, which are known for their considerable insecticidal effects. Our data suggest that the organic leaf extracts of $T$. diversifolia and V. lasiopus have considerable insecticidal properties and would, therefore, be a valuable bioprotective agent for stored maize grains against $S$. zeamais.
\end{abstract}

\section{Introduction}

Postharvest losses due to storage pests have been recognized as an increasingly important constraint to maize production. In spite of the great value of maize, its availability and utilization have been impaired due to grain damage caused by notorious postharvest insect pests in developing countries. Maize weevil, S. zeamais (Coleoptera: Curculionidae), is a small agricultural insect pest in the beetle family Curculionidae (snout beetles). It is the single most important primary pest that attacks stored maize grains, among others insect pests such as the larger grain borer Prostephanus truncatus Horn (Coleoptera: Bostrychidae) $[1,2]$. Weevil infestation causes an estimated annual loss of $30-50 \%$ of stored maize grains in tropical Africa [3].

Farmers normally control insect pests using synthetic insecticides. However, these chemicals are expensive and are 
arguably associated with deleterious side effects on the environment. The synthetic pesticides invoke resistance over time. Insecticide resistance among strains of maize weevil has been found to different registered synthetic grain protectants such as deltamethrin, Primiphos-methyl, permethrin, and Lindane and may become a much more serious problem in the future $[4,5]$.

The toxicity effects of pesticides on insects such as weevils have different possible physiological end points which practically impose toxic effects that kill the targeted pests [6-8]. Pesticides can be inhaled (fumigants), ingested, or absorbed via the insect body surface due to the abrasive effect on the pest cuticle as contact toxicants [9]. Although with some exceptions, an ingested insecticide will induce a more severe response than the same amount of insecticide encountered by an insect through direct contact or fumigation [10].

The nonconventional methods employed to control weevils on stored maize include the use of inert dusts, sanitary pest control methods involving consistent cleaning and disinfestation of storage structures, freezing, and use of ionizing radiation, as well as the use of hermetic techniques [11-13].

Medicinal plants are also importantly used in the control of weevils in stored grains. They include Azadirachta indica, Tanaecium nocturnum, Pogostemon cablin, T. diversifolia, and V. lasiopus, among others [14]. Tithonia diversifolia and Vernonia lasiopus plants have numerous medicinal values among various societies. Tithonia diversifolia is reported to exhibit antifungal, anti-inflammatory, analgesic, antimalarial, antiviral, antidiabetic, antidiarrhoeal, antimicrobial, antispasmodic, vasorelaxant and cancer chemopreventive, and antibacterial activities $[15,16]$. There are also scientific reports on the biological properties of $T$. diversifolia against arthropods. For instance, T. diversifolia is reported to elicit significant toxic impacts against dog fleas (Ctenocephalides canis (Curtis) and jigger (Tunga penetrans), as well as Callosobruchus maculatus Fab. and Sitophilus zeamais [17-22].

Different plant materials of Vernonia lasiopus have also exhibited antifungal and antimalarial activities among others [1]. It is applied on cattle bodies to control livestock ticks (Boophilus microplus) in pastoralist communities in Kenya [23]. The leaves and stem decoction of $V$. lasiopus is used by herbalists in Eastern Province, Kenya, to treat malaria, helminths, and nonbacterial infections [24]. Farmers in Embu County, Kenya, use the leaves of $T$. diversifolia and V. lasiopus on stored maize cobs to protect them against weevil infestation. However, no scientific research has been conducted to evaluate this described effect. It is against this background that this study was designed to explore and provide information on the contact toxicity effects of the selected organic extracts from $T$. diversifolia and $V$. lasiopus against adult $S$. zeamais.

\section{Materials and Methods}

2.1. Plant Sample Collection. The plants used in this study, $T$. diversifolia and $V$. lasiopus, were collected from their natural habitat in Makunguru Village, Nthawa Location,
Siakago division, Mbeere North subcounty, Embu County, Kenya. The GPS locations for T. diversifolia and V. lasiopus specimens were $0^{\circ} 35^{\prime} 39^{\prime \prime} \mathrm{S}, 37^{\circ} 38^{\prime} 10^{\prime \prime} \mathrm{E}$ and $0^{\circ} 35^{\prime} 39.51^{\prime \prime} \mathrm{S}$, $37^{\circ} 38^{\prime} 23.62^{\prime \prime} \mathrm{E}$, respectively. The fresh leaves were identified and collected from mature plants with the help of local herbalists. The folklore information obtained included the local name of the plants, part of plants harvested, season of harvesting, method of preparation, and other medicinal importance of the plants. Samples were properly sorted out, cleaned, and transported in bags to Kenyatta University, in the Biochemistry, Microbiology, and Biotechnology departmental laboratories. The plant samples were provided to an acknowledged taxonomist for botanical authentication and voucher specimens deposited at the Kenyatta University Pharmacy and Complementary/Alternative Medicine research herbaria.

2.2. Sample Preparation and Extraction. The leaves of $T$. diversifolia and $V$. lasiopus were air-dried separately under shade and at room temperature for a period of two weeks. The leaves were separately ground into fine powder using a grinding electric mill and sieved using a $300 \mu \mathrm{m}$ mesh. The powder was used for extraction following the guideline used by Singh [25]. Extraction was separately conducted with dichloromethane (DCM) and ethyl acetate to ensure maximum extraction of a wide variety of compounds [26].

Two hundred grams of each plant leaf powder was separately soaked in $200 \mathrm{ml}$ of the respective solvents for 12 hours. The extracts were decanted and $200 \mathrm{ml}$ of solvent was added and set for 24 hours. After 24 hours, filtration was carried out again and $200 \mathrm{ml}$ of the respective solvent was added for the final extraction until 48 hours when the last filtrate was obtained. Occasional swirling was performed to ensure thorough extraction. Aluminum foil and cotton wool were always used to cover the flasks to prevent escape of solvent. Muslin cloth and Whatman No. 1 papers were used for the filtration of the extracts. The extract filtrates were then concentrated in vacuum using the Heidolph rotary evaporator, and the solvent was recovered. The concentrates were further allowed to dry to remove traces of the solvents and yield dry extracts. All extracts were later kept in sample bottles and refrigerated $\left(4^{\circ} \mathrm{C}\right)$ awaiting use in pesticidal bioassays. The percent extraction yields of the DCM and EtOAc leaf extracts of the two plants were determined using the following formula:

$$
\text { Percent }(\%) \text { extract yield }=\frac{\text { mass of extract obtained }(\mathrm{g})}{\text { mass of sample }(\mathrm{g})} \times 100 .
$$

2.3. Preparation of Extract Concentrations. The plant extract concentrates were diluted with the respective solvents at a concentration of $1 \mathrm{gml}^{-1}$, and this was termed as the stock solution (100\% v/v concentration) as described by Deshmukh and Borie [27] with limited modifications. The concentrations used were 25\% (v/v), 50\% (v/v), 75\% (v/v), 
and $100 \%(\mathrm{v} / \mathrm{v})$. These extract concentrations were prepared as follows: the $25 \%(\mathrm{v} / \mathrm{v})$ concentration was prepared by diluting $1 \mathrm{ml}$ of the stock solution with $3 \mathrm{ml}$ of solvent to make up $4 \mathrm{ml}$. The $50 \%(\mathrm{v} / \mathrm{v})$ concentration was prepared by diluting $2 \mathrm{ml}$ of the stock solution with $2 \mathrm{ml}$ of the solvent to make up $4 \mathrm{ml}$, while for the $75 \%(\mathrm{v} / \mathrm{v})$ concentration, $1 \mathrm{ml}$ of the solvent was added to $3 \mathrm{ml}$ of stock solution to make up $4 \mathrm{ml}$.

2.4. Preparation of Maize Grains. To eliminate the effect of varietal resistance to $S$. zeamais infestation, a susceptible maize variety was obtained as a test variety for use in this study [21]. The experimental grains were cleaned and standardized using the method of Sulherie et al. [28]. The damaged kernels were sorted out and the clean ones were put in a deep freezer at $-20^{\circ} \mathrm{C}$ for three days to eliminate any eggs, larvae, pupae, or adult weevils. The dead weevils were sieved out and grain aired for 72 hours prior to use. This acclimatization of the maize grains stabilized the moisture content at $12-13 \%$, thereby ensuring its suitability for feeding by weevils [16].

\subsection{Rearing and Sexing of Maize Weevil (Sitophilus zeamais).} A stock culture of the maize weevil, S. zeamais, was initiated by collecting adult weevils from infested maize grains and cultured in their food media (susceptible whole maize grains) under fluctuating ambient temperature and relative humidity. Two hundred unsexed adult weevils were introduced into five two 21 bottles with $500 \mathrm{~g}$ of maize. The insects were allowed to oviposit for seven days after which they were sieved out and subsequently used for the bioassay experiments. The insect stock culture was further maintained in glass bottles of 21 capacity containing maize grains. The weevils were reared subsequently by replacing devoured and infested grains with fresh, clean, uninfected grains in containers covered with muslin cloth to allow for air circulation and prevent escape of insects. The muslin cloths covering the containers were held in place with rubber bands. The maize dust was periodically sieved to prevent the growth of mould, which may lead to the caking of grains and ultimate death of the insects. Sitophilus zeamais breeding and experiments were conducted at an ambient temperature of $27 \pm 2^{\circ} \mathrm{C}$, relative humidity of $75 \pm 5.5 \%$, and suitable photoperiod (LD $12: 12$ ). The culture maintained was used throughout the period of this study.

The weevils were sexed morphologically under a dissecting microscope using the methods of Ojo and Owoloye [29] by examining the weevil's rostrum and abdominal shape of the insects. Male S. zeamais were identified with a rough, distinctly shorter, and wider rostrum, while the female was identified with a smooth, shiny, distinctly longer, and narrower rostrum than that of the male. The male and female weevils were, hence, separated into different insect stock jars.

2.6. Gas Chromatography-Mass Spectrometry (GC-MS) Analysis. Gas Chromatography-Mass Spectrometry (GCMS) analysis of the DCM and ethyl acetate leaf extracts of
$T$. diversifolia and $V$. lasiopus was performed using the procedure previously used by Dar et al. [30]. Analysis of the sample was carried out using GC-MS (7890/5975, Agilent Technologies, Inc., Beijing, China) consisting of a gas chromatograph interfaced to a mass spectrometer.

The GC-MS was equipped with an HP-5 MS (5\% phenyl methyl siloxane) low-bleed capillary column of $30 \mathrm{~m}$ length, $0.25 \mathrm{~mm}$ diameter, and $0.25 \mu \mathrm{m}$ film thickness. For GC-MS detection, an electron ionization system with an ionization energy of $70 \mathrm{Ev}$ was used. The carrier gas used was helium (99.99\%) at a constant flow rate of $1.25 \mathrm{ml} / \mathrm{min}$ in the split mode. The injector and mass transfer line temperature were set at $250^{\circ} \mathrm{C}$ and $200^{\circ} \mathrm{C}$, respectively, and an injection volume of $1 \mu \mathrm{l}$ was employed. The oven temperature was programmed from $35^{\circ} \mathrm{C}$ for 5 minutes, with an increase of $10^{\circ} \mathrm{C} /$ minute to $280^{\circ} \mathrm{C}$ for 10.5 minutes and then $50^{\circ} \mathrm{C} /$ minute to $285^{\circ} \mathrm{C}$ for 29.9 minutes with a run time of 70 minutes. The MS operating parameters were ionization energy: $70 \mathrm{eV}$; ion source temperature: $230^{\circ} \mathrm{C}$, solvent cut time: 3.3 minutes, scan speed: $1666 \mu /$ second; scan range: $40-550 \mathrm{~m} / \mathrm{z}$; and interface temperature: $250^{\circ} \mathrm{C}$. Interpretation of mass spectrum from GC-MS analysis was performed using the central database of the National Institute of Standard and Technology (NIST), which contains more than 62,000 patterns. As for the unknown components, their spectrum was compared with those which are known from the NIST library [30].

2.7. Experimental Design. The determination of contact toxicity experiments adopted a randomized controlled study design (RCD) with four replications. The experiments were set up into six independent treatment groups (Table 1) with four replicates $(n=4)$ per treatment group. In the negative control, maize grains were treated with the respective solvent only, while for the positive control group, the grains were treated with Actellic Super ${ }^{\mathrm{TM}}$ at a recommended dose of $50 \mathrm{~g} /$ $90 \mathrm{~kg}$ grains.

Determination of contact toxicity tests was carried out as follows: twenty grams of maize grains were weighed and put into $50 \mathrm{ml}$ plastic vials. $1.0 \mathrm{ml}$ of each plant extract at predetermined concentrations of $25,50,75$, and $100 \%$ was added. The mixture was shaken gently to ensure uniform coating of grains. After the grains and extracts were thoroughly mixed, the setups were air-dried for 2 hours to evaporate all traces of solvents. Twenty male adult $S$. zeamais were introduced into each plastic vial and then tightly covered with a lid. Several tiny openings were made on the lid of the plastic vials to ensure ventilation.

Weevil mortality as a result of fumigant and contact toxicity was assessed $6,24,48,72$, and 96 hours after the insects were exposed to the extracts. After these test observation periods, the plastic vials were opened and the weevils transferred into an open recovery tray for five minutes before mortality was assessed. The insects were confirmed dead if they could not move their appendages when probed with a sharp pin on the abdomen [31]. Corrected mortality percentages were then computed using Abbort formula [32]: 
TABLE 1: Treatment protocol for determination of contact toxicity effects.

\begin{tabular}{lc}
\hline Group & Treatment \\
\hline I (negative control) & Solvents only \\
II (positive control) & Actellic Super ${ }^{\mathrm{TM}}$ \\
III (experimental group A) & $25 \%$ (v/v) plant leaf extract \\
IV (experimental group B) & $50 \%$ (v/v) plant leaf extract \\
V (experimental group C) & $75 \%$ (v/v) plant leaf extract \\
VI (experimental group D) & $100 \%$ (v/v) plant leaf extract \\
\hline
\end{tabular}

Actellic Super ${ }^{\mathrm{TM}}=50 \mathrm{~g} / 90 \mathrm{~kg}$ grain; solvents $=1 \mathrm{ml} \mathrm{DCM} /$ EtOAc.

$$
P_{r}=\frac{\mathrm{Pt}-\mathrm{Pc}}{100-\mathrm{Pc}} \times 100,
$$

where $P_{r}=$ corrected mortality.

$P_{t}=\%$ mortality in various extracts treatments $((D n / T n)(D n / T n)(D n / T n) \times 100 / 1)$

$P_{c}=\%$ mortality in solvent control

$((D n / T n)(D n / T n) \times 100 / 1)$

$D_{n}=$ number of dead insects

$T_{n}=$ total number of insects

2.8. Data Management and Statistical Analysis. The number of dead weevils $\left(D_{n}\right)$ was obtained from the different groups for each of the two plant extracts at the five test durations. The data obtained were recorded and later tabulated on a broad sheet. Corrected percent weevil mortalities (Pr) were formulated and computed using Ms Excel program. The data were checked for normality using the Kolmogorov-Smirnov test and then analyzed through descriptive statistics and presented as mean \pm SEM. The data from different treatment groups were also subjected to inferential statistics using oneway ANOVA followed by Tukey's post hoc test for separation and pairwise comparisons of means. The significant difference between the treatment groups was reported at $p \leq 0.005$. The resulting data of this study were presented in the form of tables and bar graphs. Unpaired Student's $t$-test was used for pairwise separation and comparison of means between different treatment groups for the two plants. The analyses were conducted using Minitab version 17 software as the statistical tool.

2.9. Quantitative Phytochemical Analysis of the Selected Organic Leaf Extract of $T$. diversifolia and $V$. lasiopus. The GC-MS analysis of the organic leaf extract of $T$. diversifolia and V. lasiopus revealed the presence of several phytocompounds as presented in Tables 2 and 3. Results of percentage (\%) extract yields applied in determining the concentration (ng/g) of the phytochemical revealed in the organic leaf extracts of the two are tabulated in Table 4. The dichloromethanolic extracts of $T$. diversifolia had the highest yield of $1.69 \%$ followed by ethyl acetate extracts of T. diversifolia (1.44\%) (Table 4). The dichloromethanolic and ethyl acetate extracts of $V$. lasiopus had the lowest yield of 0.56 and $0.54 \%$, respectively (Table 4 ). The GC-MS results of the present study showed the presence of active insecticidal compounds in the organic leaf extracts of T. diversifolia and
$V$. lasiopus. These compounds include lipids (fatty acid esters and phytosterols), terpenoids (monoterpenes, diterpenes, triterpenes, and sesquiterpenoids), and phenolic compounds (Tables 2 and 3).

2.10. Contact Toxicity Effects of DCM Leaf Extracts of $T$. diversifolia and V. lasiopus against $S$. zeamais. As Tables 3 and 5 show, the DCM leaf extracts of $T$. diversifolia and $V$. lasiopus generally caused remarkable weevil mortality upon contact. It was observed that the two plants manifested an increase in weevil mortality with an increase in exposure time to weevils throughout the experimental period. In this study, the solvent (dichloromethane) was reported to have no weevil-killing potential throughout the experimental period (Tables 5 and 6).

The $T$. diversifolia extract caused dose-dependent effects, except in the first and second observation times of 6 and 24 hours after exposure to weevils. Six hours after exposure to weevils, the $T$. diversifolia extract dose of $75 \%$ evoked the highest weevil mortality of $36.25 \%$. However, this was not significantly different from the effects caused by the rest of the extract concentrations ( $p>0.005$; Table 5).

Twenty-four hours after exposure to weevils, the T. diversifolia extract dose of $75 \%$ caused the least weevil mortality $(72.47 \%)$, which was significantly lower than the effects caused by the other dosages $(p<0.005$; Table 5$)$. At the same time, the $T$. diversifolia extract doses of 25,50 , and $100 \%$ evoked statistically similar weevil-killing abilities, which also matched the effects caused by Actellic Super ${ }^{\mathrm{TM}}$ ( $p>0.005$; Table 5).

Following 48, 72, and 96 hours of exposure to weevils, the contact toxicity effect of the $T$. diversifolia extract at all concentrations was comparable to each other $(p>0.005$; Table 5). Furthermore, the effects caused by the T. diversifolia extract concentrations were found to be statistically comparable to the effects of the standard pesticide, Actellic Super ${ }^{\text {тм }}$, after these long durations of exposure to $S$. zeamais ( $p>0.005$; Table 5).

On the other hand, the DCM leaf extracts of $V$. lasiopus also demonstrated considerable dose-dependent contactinduced weevil mortality. However, it was apparent that none of the $V$. lasiopus extracts caused weevil mortality in a comparable fashion to that caused by the standard pesticide, Actellic Super ${ }^{\text {тм }}(p<0.005$; Table 6).

The $V$. lasiopus extract concentrations of 25 and 50\% caused comparable weevil mortality throughout the experimental period $(p>0.005$; Table 6$)$. The two highest 
TABle 2: Phytochemical analysis of insecticidal compounds in the DCM leaf extract of T. diversifolia and V. lasiopus.

\begin{tabular}{|c|c|c|c|c|c|c|}
\hline \multirow{2}{*}{ Compound name } & \multirow{2}{*}{ Chemical class } & \multirow{2}{*}{ Molecular formula } & \multicolumn{2}{|c|}{ T. diversifolia } & \multicolumn{2}{|c|}{ V. lasiopus } \\
\hline & & & RT & Conc. (ng/g) & RT & Conc. (ng/g) \\
\hline Squalene & TD & $\mathrm{C}_{30} \mathrm{H}_{50}$ & 30.85 & 392.50 & 30.85 & 149.90 \\
\hline Phytol acetate & DT & $\mathrm{C}_{22} \mathrm{H}_{42} \mathrm{O}_{2}$ & 22.29 & 254.59 & 22.29 & 170.93 \\
\hline Methyl linoleate & DT & $\mathrm{C}_{19} \mathrm{H}_{34} \mathrm{O}_{2}$ & 25.15 & 164.40 & 25.39 & 164.40 \\
\hline Phytol & DT & $\mathrm{C}_{20} \mathrm{H}_{40} \mathrm{O}$ & 24.96 & 159.82 & 24.96 & 051.17 \\
\hline Isophytol & DT & $\mathrm{C}_{20} \mathrm{H}_{40} \mathrm{O}$ & 23.38 & 007.05 & - & - \\
\hline Eugenol & $\mathrm{P}$ & $\mathrm{C}_{10} \mathrm{H}_{12} \mathrm{O}_{2}$ & 16.68 & 009.53 & 16.71 & 005.30 \\
\hline Linalool & MT & $\mathrm{C}_{10} \mathrm{H}_{18} \mathrm{O}$ & 12.80 & 007.34 & - & - \\
\hline Chondrillasterol & $\mathrm{ST}$ & $\mathrm{C}_{29} \mathrm{H}_{48} \mathrm{O}$ & - & - & 37.63 & 067.52 \\
\hline Methyl linoleate & FAD & $\mathrm{C}_{19} \mathrm{H}_{34} \mathrm{O}_{2}$ & 25.15 & 164.40 & 25.39 & 043.03 \\
\hline 1-Nonadecene & FAD & $\mathrm{C}_{19} \mathrm{H}_{38}$ & - & - & 21.12 & 003.18 \\
\hline
\end{tabular}

P stands for phenolic, ST for sesquiterpenoid, TT for triterpenoid, DT for diterpenoid, MT formonoterpenoid, S for phytosterol, AD for aldehyde, and FAD for fatty acid derivatives. Figures in parenthesis indicate retention time (RT).

TABle 3: Phytochemical analysis of insecticidal compounds in the ethyl acetate leaf extracts of T. diversifolia and V. lasiopus.

\begin{tabular}{|c|c|c|c|c|c|c|}
\hline \multirow{2}{*}{ Compound name } & \multirow{2}{*}{ Chemical class } & \multirow{2}{*}{ Molecular formula } & \multicolumn{2}{|c|}{ T. diversifolia } & \multicolumn{2}{|c|}{ V. lasiopus } \\
\hline & & & RT & Conc. (ng/g) & RT & Conc. (ng/g) \\
\hline Nonanoic acid & FAD & $\mathrm{C}_{9} \mathrm{H}_{18} \mathrm{O}_{2}$ & 15.34 & 008.05 & - & - \\
\hline Squalene & $\mathrm{TT}$ & $\mathrm{C}_{30} \mathrm{H}_{50}$ & - & - & 30.84 & 122.41 \\
\hline$\alpha$-Pinene & $\mathrm{MT}$ & $\mathrm{C}_{10} \mathrm{H}_{16}$ & - & - & 09.59 & 004.53 \\
\hline Methyl linoleate & FAD & $\mathrm{C}_{19} \mathrm{H}_{34} \mathrm{O}_{2}$ & 25.18 & 370.28 & 25.13 & 121.30 \\
\hline Phytol & DT & $\mathrm{C}_{20} \mathrm{H}_{40} \mathrm{O}$ & 24.97 & 321.37 & 24.95 & 060.40 \\
\hline Phytol acetate & DT & $\mathrm{C}_{22} \mathrm{H}_{42} \mathrm{O}_{2}$ & 25.90 & 087.95 & 22.28 & 233.70 \\
\hline Sabinene & MT & $\mathrm{C}_{10} \mathrm{H}_{18} \mathrm{O}$ & - & - & 12.25 & 004.57 \\
\hline Eugenol & $\mathrm{P}$ & $\mathrm{C}_{10} \mathrm{H}_{12} \mathrm{O}_{2}$ & 16.68 & 016.89 & - & - \\
\hline Coryophyllene & ST & $\mathrm{C}_{15} \mathrm{H}_{24} \mathrm{O}$ & 19.65 & 019.33 & 19.65 & 011.87 \\
\hline Linalool & MT & $\mathrm{C}_{10} \mathrm{H}_{18} \mathrm{O}$ & - & - & 12.79 & 007.58 \\
\hline Limonene & MT & $\mathrm{C}_{10} \mathrm{H}_{16}$ & - & - & 11.55 & 005.06 \\
\hline Citronellel & FAD & $\mathrm{C}_{14} \mathrm{H}_{26} \mathrm{O}_{2}$ & 22.54 & 116.29 & - & - \\
\hline Terpinen-4-ol & MT & $\mathrm{C}_{10} \mathrm{H}_{18} \mathrm{O}_{0}$ & 14.08 & 006.58 & 14.08 & 005.84 \\
\hline L- $\alpha$-terpineol & MT & $\mathrm{C}_{14} \mathrm{H}_{22}$ & 14.29 & 003.47 & - & - \\
\hline
\end{tabular}

P stands for phenolic, ST for sesquiterpenoid, TT for triterpenoid, DT for diterpenoid, MT for monoterpenoid, S for phytosterol, AD for aldehyde, and FAD for fatty acid derivatives. Figures in parenthesis indicate retention time (RT).

TABLE 4: The percentage (\%) of crude extraction yields.

\begin{tabular}{lccc}
\hline Plant under study & Type of extract & Mass of crude extract $(\mathrm{g})$ & Yield of crude extract (\%) \\
\hline \multirow{2}{*}{ T. diversifolia } & DCM extract & 3.38 & 1.69 \\
& EtOAc extract & 2.88 & 1.44 \\
\hline \multirow{2}{*}{ V. lasiopus } & DCM extract & 1.12 & 0.56 \\
& EtOAc extract & 1.07 & 0.54 \\
\hline
\end{tabular}

DCM and EtOAc used were of analytical grade (95.5\%).

TABLE 5: Contact toxicity effects of DCM leaf extracts of T. diversifolia against S. zeamais.

\begin{tabular}{|c|c|c|c|c|c|c|}
\hline \multirow{2}{*}{ Group } & \multirow{2}{*}{ Treatment (\% extract) } & \multicolumn{5}{|c|}{ Mean percent corrected mortality (pr) with exposure period (hours) } \\
\hline & & $6 \mathrm{hr}$ & $24 \mathrm{hr}$ & $48 \mathrm{hr}$ & $72 \mathrm{hr}$ & $96 \mathrm{hr}$ \\
\hline Negative control & Solvent only & $00.00 \pm 0.00^{\mathrm{c}}$ & $00.00 \pm 0.00^{\mathrm{c}}$ & $00.00 \pm 0.00^{\mathrm{b}}$ & $00.00 \pm 0.00^{\mathrm{b}}$ & $00.00 \pm 0.00^{\mathrm{b}}$ \\
\hline Positive control & Actellic Super тм & $95.00 \pm 2.04^{\mathrm{a}}$ & $97.47 \pm 2.49^{\mathrm{a}}$ & $99.98 \pm 0.25^{\mathrm{a}}$ & $99.95 \pm 0.29^{\mathrm{a}}$ & $99.93 \pm 0.03^{\mathrm{a}}$ \\
\hline \multirow{4}{*}{ DCM leaf extract } & $25 \%(\mathrm{v} / \mathrm{v})$ & $25.00 \pm 0.00^{\mathrm{b}}$ & $92.50 \pm 2.50^{\mathrm{a}}$ & $92.50 \pm 2.50^{\mathrm{a}}$ & $94.95 \pm 0.05^{\mathrm{a}}$ & $97.40 \pm 2.50^{\mathrm{a}}$ \\
\hline & $50 \%(\mathrm{v} / \mathrm{v})$ & $33.75 \pm 2.39^{\mathrm{b}}$ & $89.97 \pm 4.56^{\mathrm{a}}$ & $94.97 \pm 2.87^{\mathrm{a}}$ & $97.45 \pm 1.41^{\mathrm{a}}$ & $98.68 \pm 1.23^{\mathrm{a}}$ \\
\hline & $75 \%(\mathrm{v} / \mathrm{v})$ & $36.25 \pm 3.15^{\mathrm{b}}$ & $72.47 \pm 3.23^{\mathrm{b}}$ & $94.97 \pm 2.06^{\mathrm{a}}$ & $98.70 \pm 1.27^{\mathrm{a}}$ & $99.93 \pm 0.03^{\mathrm{a}}$ \\
\hline & $100 \%(\mathrm{v} / \mathrm{v})$ & $33.75 \pm 4.27^{\mathrm{b}}$ & $98.72 \pm 1.24^{\mathrm{a}}$ & $99.98 \pm 0.03^{\mathrm{a}}$ & $99.95 \pm 0.02^{\mathrm{a}}$ & $99.93 \pm 0.03^{\mathrm{a}}$ \\
\hline
\end{tabular}

Values are expressed as mean \pm SEM for four replicates per group $(n=4)$. Statistical comparisons were made within a column, and values followed by the same superscripts along the column are not significantly different by one-way ANOVA $(p \geq 0.005)$ followed by Tukey's post hoc test. Actellic Super ${ }^{\mathrm{TM}}=50 \mathrm{~g} / 90 \mathrm{~kg}$ of maize grains; solvents $=1 \mathrm{ml} \mathrm{DCM} / \mathrm{EtOAc}$. 
TABLE 6: Contact toxicity effects of DCM leaf extracts of $V$. lasiopus against S. zeamais.

\begin{tabular}{|c|c|c|c|c|c|c|}
\hline \multirow{2}{*}{ Group } & \multirow{2}{*}{ Treatment (\% extract) } & \multicolumn{5}{|c|}{ Mean percent corrected mortality (pr) with exposure period (hours) } \\
\hline & & $6 \mathrm{hr}$ & $24 \mathrm{hr}$ & $48 \mathrm{hr}$ & $72 \mathrm{hr}$ & $96 \mathrm{hr}$ \\
\hline Negative control & Solvent only & $00.00 \pm 0.00^{\mathrm{d}}$ & $00.00 \pm 0.00^{\mathrm{d}}$ & $00.00 \pm 0.00^{\mathrm{e}}$ & $00.00 \pm 0.00^{\mathrm{d}}$ & $00.00 \pm 0.00^{\mathrm{e}}$ \\
\hline Positive control & Actellic Super ${ }^{\mathrm{TM}}$ & $95.00 \pm 2.04^{\mathrm{a}}$ & $97.47 \pm 2.49^{\mathrm{a}}$ & $99.98 \pm 0.25^{\mathrm{a}}$ & $99.95 \pm 0.29^{\mathrm{a}}$ & $99.93 \pm 0.03^{\mathrm{a}}$ \\
\hline \multirow[t]{4}{*}{ DCM leaf extract } & $25 \%(\mathrm{v} / \mathrm{v})$ & $01.67 \pm 1.67^{\mathrm{d}}$ & $06.63 \pm 1.63^{\mathrm{d}}$ & $18.30 \pm 3.30^{\mathrm{d}}$ & $24.93 \pm 4.98^{\mathrm{c}}$ & $31.57 \pm 1.67^{\mathrm{d}}$ \\
\hline & $50 \%(\mathrm{v} / \mathrm{v})$ & $02.50 \pm 2.50^{\mathrm{d}}$ & $11.23 \pm 2.38^{\mathrm{d}}$ & $18.73 \pm 2.39^{\mathrm{d}}$ & $26.20 \pm 3.15^{\mathrm{c}}$ & $32.43 \pm 1.43^{\mathrm{d}}$ \\
\hline & $75 \%(\mathrm{v} / \mathrm{v})$ & $25.00 \pm 2.04^{\mathrm{c}}$ & $29.98 \pm 2.06^{\mathrm{c}}$ & $31.23 \pm 2.42^{\mathrm{C}}$ & $43.70 \pm 3.14^{b}$ & $54.93 \pm 2.06^{\mathrm{c}}$ \\
\hline & $100 \%(\mathrm{v} / \mathrm{v})$ & $36.25 \pm 1.25^{\mathrm{b}}$ & $46.23 \pm 1.23^{\mathrm{b}}$ & $47.48 \pm 1.43^{\mathrm{b}}$ & $57.45 \pm 3.20^{\mathrm{b}}$ & $66.18 \pm 1.24^{\mathrm{b}}$ \\
\hline
\end{tabular}

Values are expressed as mean \pm SEM for four replicates per group $(n=4)$. Statistical comparisons were made within a column, and values followed by the same superscripts along the column are not significantly different by one-way ANOVA $(p \geq 0.005)$ followed by Tukey's post hoc test. Actellic Super ${ }^{\mathrm{TM}}=50 \mathrm{~g} / 90 \mathrm{~kg}$ of maize grains; solvents $=1 \mathrm{ml} \mathrm{DCM} / \mathrm{EtOAc}$.

extract concentrations (75 and $100 \%$ ) caused significantly different weevil mortalities upon contact $(p<0.005$; Table 6$)$. This was only in exception of the observation noted after 72 hours of exposure to weevils, when the two dosages caused statistically similar mortalities of 43.7 and $57.45 \%$, respectively ( $p>0.005$; Table 6$)$. However, these effects were significantly lower than the effects of the reference pesticide, Actellic Super ${ }^{\text {Tм }}(p<0.005$; Table 6).

In comparison, it was observed that the DCM leaf extract of $T$. diversifolia generally evoked a more effective weevilkilling potential as compared to the $V$. lasiopus extract (Figure 1). Nevertheless, following 6 hours of exposure to weevils, the extracts of both $T$. diversifolia and V. lasiopus, at the doses of 75 and $100 \%$, showed no significant difference in their effectiveness ( $p>0.005$; Figure 1). However, during the rest of the experimental period, the $T$. diversifolia extract remained significantly the most potent plant against S. zeamais $(p<0.005$; Figure 1$)$.

2.11. Contact Toxicity Effects of the Ethyl Acetate Leaf Extract of $T$. diversifolia and $V$. lasiopus against $S$. zeamais. Overall, the ethyl acetate leaf extracts of $T$. diversifolia and $V$. lasiopus demonstrated weevil-killing ability, which increased with the increase in extract dosage (Tables 7 and 8). The effectiveness of these plant extracts was also found to increase with an increase in exposure time to maize weevils. The weevils in the negative control group were found alive, showing zero percent mortality (Tables 7 and 8).

This study demonstrated that, apart from the T. diversifolia extract dose of $100 \%$, none of the other dosages showed weevil mortality comparable to that caused by Actellic Super ${ }^{\mathrm{TM}}$ following a short duration (six hours) of exposure to weevils ( $p \leq 0.005$; Table 7$)$. In the rest of the experimental period, it was found that the $T$. diversifolia extract doses of 75 and $100 \%$ were as effective as the standard pesticide, Actellic Super ${ }^{\mathrm{Tм}}$ ( $p>0.005$; Table 7$)$.

After 48 and 72 hours of exposure to weevils, the effectiveness of the T. diversifolia extract doses of 25 and $50 \%$ was found to be comparable to each other $(p>0.005)$ although significantly lower than that of the rest of the treatments ( $p \leq 0.005$; Table 7$)$. At the last observation time (96 hours after exposure), the T. diversifolia extract dose of
$50 \%$ was found to be equally effective as the extract doses of 75 and $100 \%$ as well as the reference pesticide, Actellic Super тм ( $p>0.005$; Table 7).

Similarly, the ethyl acetate leaf extract of $V$. lasiopus also caused dose-dependent weevil mortality, which increased with an increase in exposure time. Six hours after exposure to weevils, the $V$. lasiopus extract evoked weevil mortalities of $12.50,23.75,32.50$, and $41.25 \%$ at doses of $25,50,75$, and $100 \%$, respectively. These effects were significantly different from those reported by both positive and unprotected grain samples $(p<0.005$; Table 8$)$.

It was apparent that the effectiveness of the $V$. lasiopus extract at low doses of 25 and 50\% was not significantly different from each other $(p>0.005)$ except after 48 hours of exposure. Likewise, the high extract doses (75 and 100\%) evoked statistically similar weevil mortality except after 24 hours of the $V$. lasiopus extract exposure to weevils $(p>0.005$; Table 8$)$.

This study further demonstrated that the effect of the $V$. lasiopus extract did not match the effectiveness of the synthetic pesticides after a short duration of exposure to weevils (<48 hours). However, the higher extract dosages of $V$. lasiopus (75 and 100\%) evoked mortalities which were comparable to each other as well to the effect caused by Actellic Super ${ }^{\mathrm{TM}}$ following a long duration of exposure to weevils (72 and 96 hours) ( $p>0.005$; Table 8 ). It was also evident that, after long durations of exposure to weevils (72 and 96 hours), the $V$. lasiopus extract doses of 25 and $50 \%$ remained equally effective $(p>0.005)$ but significantly lower than other treatments $(p \leq 0.005$; Table 8$)$.

Upon comparison, the ethyl acetate leaf extract of $T$. diversifolia generally demonstrated more potent weevilkilling ability as compared to the $V$. lasiopus extract (Figure 2). All concentrations of the $T$. diversifolia extract showed significantly higher weevil mortality after 6,24 , and 48 hours of exposure to the weevils than the effects of the $V$. lasiopus extract ( $p \leq 0.005$; Figure 2$)$.

However, following 72 hours of exposure to weevils, the $100 \%$ dose of the two plants showed no significant statistical difference in their effectiveness against $S$. zeamais $(p>0.005$; Figure 2). At the observation time of 96 hours, the two extracts, at extract concentrations of 25,75 , and $100 \%$, were equally effective against $S$. zeamais ( $p>0.005$; Figure 2 ). 


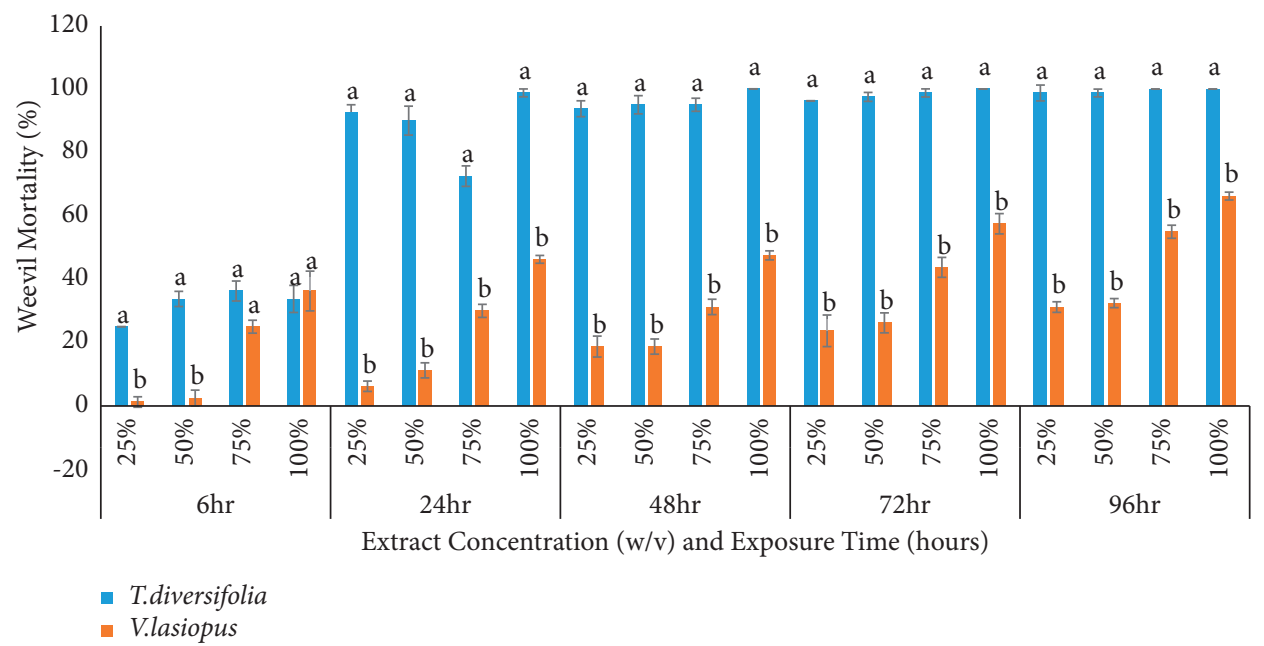

Figure 1: Comparison of the contact toxicity effects (corrected percent mortality) of the DCM leaf extracts of T. diversifolia and V. lasiopus against $S$. zeamais. Bar graphs with different superscripts within the same concentration are significantly different at the respective test period $(p<0.005)$.

TABle 7: Contact toxicity effects of the ethyl acetate leaf extract of T. diversifolia against S. zeamais.

\begin{tabular}{|c|c|c|c|c|c|c|}
\hline \multirow{2}{*}{ Group } & \multirow{2}{*}{ Treatment (\% extract) } & \multicolumn{5}{|c|}{ Mean percent corrected mortality (pr) with exposure period (hours) } \\
\hline & & $6 \mathrm{hr}$ & $24 \mathrm{hr}$ & $48 \mathrm{hr}$ & $72 \mathrm{hr}$ & $96 \mathrm{hr}$ \\
\hline Negative control & Solvent only & $00.00 \pm 0.00^{\mathrm{e}}$ & $00.00 \pm 0.00^{\mathrm{d}}$ & $00.00 \pm 0.00^{\mathrm{c}}$ & $00.00 \pm 0.00^{\mathrm{c}}$ & $00.00 \pm 0.00^{\mathrm{c}}$ \\
\hline Positive control & Actellic Super ${ }^{\mathrm{TM}}$ & $95.00 \pm 2.04^{\mathrm{a}}$ & $97.47 \pm 2.49^{\mathrm{a}}$ & $99.98 \pm 0.25^{\mathrm{a}}$ & $99.95 \pm 0.29^{\mathrm{a}}$ & $99.93 \pm 0.03^{\mathrm{a}}$ \\
\hline \multirow[t]{4}{*}{ Ethyl acetate extract } & $25 \%(\mathrm{w} / \mathrm{v})$ & $31.67 \pm 1.67^{\mathrm{d}}$ & $33.30 \pm 1.65^{\mathrm{c}}$ & $35.30 \pm 1.65^{\mathrm{b}}$ & $61.60 \pm 1.65^{\mathrm{b}}$ & $74.93 \pm 2.86^{\mathrm{b}}$ \\
\hline & $50 \%(w / v)$ & $47.50 \pm 1.44^{\mathrm{c}}$ & $54.98 \pm 2.04^{\mathrm{b}}$ & $62.48 \pm 5.22^{\mathrm{b}}$ & $66.20 \pm 1.27^{\mathrm{b}}$ & $98.65 \pm 1.25^{\mathrm{a}}$ \\
\hline & $75 \%(\mathrm{w} / \mathrm{v})$ & $66.25 \pm 1.25^{\mathrm{b}}$ & $87.47 \pm 1.43^{\mathrm{a}}$ & $92.47 \pm 1.43^{\mathrm{a}}$ & $97.45 \pm 2.52^{\mathrm{a}}$ & $98.65 \pm 1.25^{\mathrm{a}}$ \\
\hline & $100 \%(\mathrm{w} / \mathrm{v})$ & $86.25 \pm 3.15^{\mathrm{a}}$ & $92.47 \pm 2.52^{\mathrm{a}}$ & $96.22 \pm 2.42^{\mathrm{a}}$ & $98.70 \pm 1.23^{\mathrm{a}}$ & $99.90 \pm 0.04^{\mathrm{a}}$ \\
\hline
\end{tabular}

Values are expressed as mean \pm SEM for four replicates per group $(n=4)$. Statistical comparisons were made within a column, and values followed by the same superscripts along the column are not significantly different by one-way ANOVA $(p \geq 0.005)$ followed by Tukey's post hoc test. Actellic Super ${ }^{\mathrm{TM}}=50 \mathrm{~g} / 90 \mathrm{~kg}$ of maize grains; solvents $=1 \mathrm{ml} \mathrm{DCM} / \mathrm{EtOAc}$.

TABLE 8: Contact toxicity effects of ethyl acetate leaf extracts of $V$. lasiopus against S. zeamais.

\begin{tabular}{|c|c|c|c|c|c|c|}
\hline \multirow{2}{*}{ Group } & \multirow{2}{*}{ Treatment (\% extract) } & \multicolumn{5}{|c|}{ Mean percent corrected mortality (pr) with exposure period (hours) } \\
\hline & & $6 \mathrm{hr}$ & $24 \mathrm{hr}$ & $48 \mathrm{hr}$ & $72 \mathrm{hr}$ & $96 \mathrm{hr}$ \\
\hline Negative control & Solvent only & $00.00 \pm 0.00^{\mathrm{e}}$ & $00.00 \pm 0.00^{\mathrm{e}}$ & $00.00 \pm 0.00^{\mathrm{e}}$ & $00.00 \pm 0.00^{\mathrm{c}}$ & $00.00 \pm 0.00^{\mathrm{c}}$ \\
\hline Positive control & Actellic Super тм & $95.00 \pm 2.04^{\mathrm{a}}$ & $97.47 \pm 2.49^{\mathrm{a}}$ & $99.98 \pm 0.25^{\mathrm{a}}$ & $99.95 \pm 0.29^{\mathrm{a}}$ & $99.93 \pm 0.03^{\mathrm{a}}$ \\
\hline \multirow[t]{4}{*}{ Ethyl acetate extract } & $25 \%(\mathrm{v} / \mathrm{v})$ & $12.50 \pm 1.44^{\mathrm{d}}$ & $13.73 \pm 2.41^{\mathrm{de}}$ & $19.98 \pm 2.04^{\mathrm{d}}$ & $28.70 \pm 2.42^{\mathrm{b}}$ & $63.65 \pm 4.28^{\mathrm{b}}$ \\
\hline & $50 \%(\mathrm{v} / \mathrm{v})$ & $23.75 \pm 2.39^{\mathrm{cd}}$ & $26.23 \pm 4.29^{\mathrm{cd}}$ & $37.46 \pm 1.43^{c}$ & $43.70 \pm 3.76^{\mathrm{b}}$ & $68.65 \pm 3.17^{b}$ \\
\hline & $75 \%(\mathrm{v} / \mathrm{v})$ & $32.50 \pm 2.50^{b c}$ & $38.73 \pm 1.24^{\mathrm{c}}$ & $71.22 \pm 3.12^{\mathrm{b}}$ & $82.45 \pm 3.21^{\mathrm{a}}$ & $93.65 \pm 2.36^{\mathrm{a}}$ \\
\hline & $100 \%(\mathrm{v} / \mathrm{v})$ & $41.25 \pm 2.39^{\mathrm{b}}$ & $54.98 \pm 2.04^{\mathrm{b}}$ & $77.47 \pm 4.80^{\mathrm{b}}$ & $84.95 \pm 7.34^{\mathrm{a}}$ & $97.40 \pm 1.44^{\mathrm{a}}$ \\
\hline
\end{tabular}

Values are expressed as mean \pm SEM for four replicates per group $(n=4)$. Statistical comparisons were made within a column, and values followed by the same superscripts along the column are not significantly different by one-way ANOVA $(p \geq 0.005)$ followed by Tukey's post hoc test. Actellic Super ${ }^{\mathrm{TM}}=50 \mathrm{~g} / 90 \mathrm{~kg}$ of maize grains; solvents $=1 \mathrm{ml}$ DCM/EtOAc.

Probit analysis was performed to obtain the $50 \%$ lethal dose of the four selected organic leaf extracts. The concentration of the selected organic leaf extracts of $T$. diversifolia and $V$. lasopus that killed $50 \%$ of the 20 weevils exposed to extracts every 24 hours for a period of 96 hours was recorded. The $\mathrm{LD}_{50}$ revealed DCM leaf extract of $T$. diversifolia to be the most effective biopesticide, while DCM leaf extract of $V$. lasopus was reported as the least effective of the tested extracts (Table 9).

\section{Discussion}

The present study was designed to assess the toxicity effects of organic leaf extracts of $T$. diversifolia and $V$. lasiopus against $S$. zeamais. It was apparent that the two plants possess contact toxicity properties on adult weevils. The extracts showed toxicity ratings that ranged between a moderately low toxicity of $31.57 \%$ and a very high toxicity of $99.93 \%$ after 96 hours of exposure to weevils. 


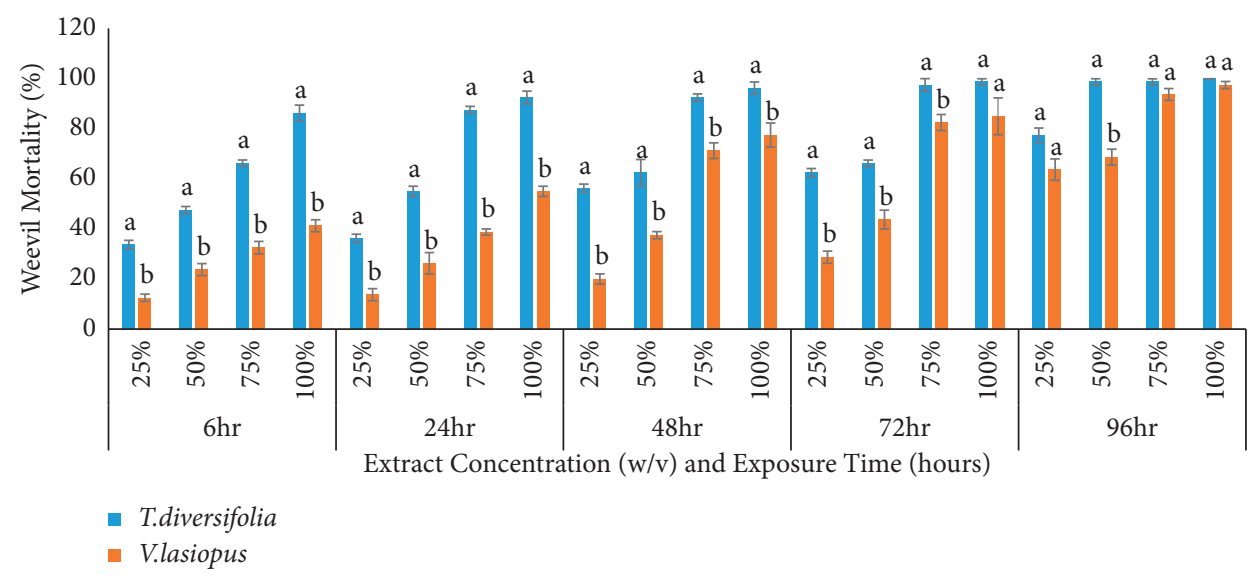

Figure 2: Comparison of the contact toxicity effects (corrected percent mortality) of ethyl acetate leaf extracts of T. diversifolia and $V$. lasiopus against $S$. zeamais. Bar graphs with different superscripts within the same concentration are significantly different at the respective test period $(p \leq 0.005)$.

TABLE 9: Lethal dose $\left(\mathrm{LD}_{50}\right)$ of selected organic leaf extracts of T. diversifolia and V. lasopus against S. zeamais in stored maize grains.

\begin{tabular}{lccccc}
\hline \multirow{2}{*}{ Plant } & Extract & \multicolumn{3}{c}{ Lethal dose $\left(\mathrm{LD}_{50}\right)$} & \multicolumn{2}{c}{} & \\
& & $24 \mathrm{~h}$ & $48 \mathrm{~h}$ & $12 \mathrm{~h}$ & $96 \mathrm{~h}$ \\
\hline \multirow{2}{*}{ T. diversifolia } & DCM & $23.17 \pm 1.92^{\mathrm{d}}$ & $19.92 \pm 1.09^{\mathrm{d}}$ & $1.96 \pm 15^{\mathrm{d}}$ & $07.29 \pm 1.32^{\mathrm{d}}$ \\
& EtOAc & $36.96 \pm 0.73^{\mathrm{c}}$ & $29.55 \pm 0.83^{\mathrm{c}}$ & $24.71 \pm 0.63^{\mathrm{c}}$ & $14.30 \pm 0.21^{\mathrm{c}}$ \\
\hline \multirow{2}{*}{ V. lasiopus } & DCM & $84.19 \pm 1.68^{\mathrm{a}}$ & $57.57 \pm 1.08^{\mathrm{a}}$ & $37.00 \pm 1.21^{\mathrm{a}}$ & $29.48 \pm 1.68^{\mathrm{a}}$ \\
& EtOAc & $57.21 \pm 0.33^{\mathrm{b}}$ & $37.40 \pm 0.88^{\mathrm{b}}$ & $30.62 \pm 1.07^{\mathrm{b}}$ & $23.84 \pm 0.93^{\mathrm{b}}$ \\
\hline
\end{tabular}

Values are expressed as mean \pm SEM for four replicates per group $(n=4)$. Statistical comparisons were made within column, and values followed by different superscripts.

The insecticidal findings of the present study are in accordance with many other studies that reported botanicals as effective controls against major stored grain pest species. There is immense scientific literature on both crude extracts of plants and isolated phytochemicals with insecticidal effects against storage pests [33]. For instance, according to Ikbal and Pavela [34], O. basilicum, M. piperita, P. anisum, M. pulegium, A. indica, and F. vulgare, among others plant species, have shown outstanding effectiveness against insects [34].

The essential oils of cinnamon, clove, rosemary, bergamot, and Japanese mint also showed effective fumigant toxicity against pulse beetle [35]. Similarly, the present findings support the results of Stoll [36], who reported that organic leaf extracts of various plants have effective toxicity against insect pests of various crops in the field and in stores. The insecticidal nature of essential oils of $P$. angolensis and $P$. quadrifolia was also manifested by contact action on adult insects of $S$. cerealella [36].

In consonance with the findings of the present study, the extracts of $T$. diversifolia, $P$. amarus, and A. albida also demonstrated $42-88 \%, 40-56 \%$, and $24-60 \%$ insect mortality, respectively [37]. Trivedi et al. [38] demonstrated 96\% fumigant toxicity against the stored grain pest Callosobruchus chinensis. Ouko et al. [39] reported up to $100 \%$ fumigant toxicity effect of hexane, a methanolic blend extract of $O$. basilicum, on adult $S$. zeamais.
To evaluate the contact toxicity effects of the alcoholic leaf extracts of $T$. diversifolia on termites, Oyedokun et al. [37] used similar test dosages used in this study and demonstrated equally high toxicity effects of $T$. diversifolia on termites. Similar laboratory-based tests were carried out to determine the toxicities of methanolic, hexane, and methanolic: hexane blend extracts of Allium sativum on maize weevils using four concentration levels of $25,50,75$, and $100 \%$ by Ouko et al. [39].

The results of this study showed a direct relationship between the level at which the plant extract treatments were applied and their effectiveness on S. zeamais. The effects of the treatments at different extract concentration levels on the $S$. zeamais were notably different from each other. In general, the bioactivities of DCM and EtOAc leaf extracts of $T$. diversifolia and V. lasiopus were directly proportional to the extract concentrations. The higher the plant extract concentration, the more potent the extract.

That the number of dead weevils increased with the increasing concentration could be due to the increase in bioactive components as the concentration of the extract increases such that it is likely that, at the lower dose, there was no sufficient concentration of the active principle(s). This variability can also be explained by the fact that the probability of feeding on the botanical insecticidal compounds along with the extract particles increases with the increase in concentration. This correlation suggests 
that the organic extracts of the two plants can best be applied at $100 \% \mathrm{v} / \mathrm{v}$ concentration to have a better kill of maize weevils. According to Ouko et al. [39], this may be due to the fact that the combination of the active phytocompounds was in the best proportional mixture for optimum insecticidal activity at $100 \% \mathrm{v} / \mathrm{v}$ extract concentration. That the higher dose such as that of $100 \%$ was not as effective as at the lower dose level of $75 \%$ may be due to the fact that the high dose takes longer to be absorbed across the insect cuticle to the targeted site.

That the insecticidal effectiveness increased with extract concentration and exposure time in this study is consistent with previous findings on the effects of organic plant extracts on various pest insects including S. zeamais, A. obtectus, B. brassicae, and T. castaneum [39-47]. The extracts manifested a higher mortality with an increased exposure time of the weevils to the treated maize grains. This observation could be explained by the fact that an increase in exposure time allows for more contact time with the target pest and, hence, permits an increase in uptake of active constituents, hence the observed higher mortality with longer exposure span.

This is consistent with other previous studies carried out using Citrullus colocynthis, Cannabis indica, and Artemisia argyi extracts against insect pests. These extracts exerted adverse effects against insect pests such as Brevicoryne brassicae L. at increasing concentrations and prolonged exposure periods [48]. The trend was also consistent with the findings in $[49,50]$ that showed a positive concentrationdependent correlation of $A$. sativum versus mortality in pulse beetle and maize weevils, respectively.

The toxicity activities of the two plant extracts on the weevils varied relatively according to the solvent used during extraction. The content and activity of the extracted phytochemicals depend on the polarity of the solvent and the solubility of the bioactive compounds in the mother solvent. Therefore, the extracting solvent plays an important role in the biocidal potency of plant crude extracts $[48,51,52]$, and this was evident in the present study.

Previous studies have shown that nonpolar organic solvents such as ethyl acetate extract, pesticidal nonpolar compounds such as terpenoids and phytosterols [53], and medium-polar solvents such as dichloromethane effectively extract flavonoids, terpenoids, phytosterols, fatty acids, alkaloids, and phenols $[53,54]$ which also exhibit pesticidal properties. Polar organic solvents such as methanol usually extract polar compounds such as amino acids, sugars, and glycosides, which are not particularly associated with pesticidal activities $[54,55]$.

The variation in the toxicity effect of the extracts in this study can, therefore, be attributed to the varying phytochemical composition of the extracts. The higher mortality exhibited by the ethyl acetate leaf extracts indicated that this organic solvent extracted more active compounds with insecticidal activity than the DCM leaf extracts. Therefore, in this study, the contact insecticide activities of EtOAc and DCM leaf extracts exhibited no significant difference, which suggests that using either of the two extraction solvents renders no difference.
The GC-MS analysis revealed that the organic leaf extracts of $T$. diversifolia and $V$. lasiopus contain phytochemical compounds which are toxic to insect pests and parasites. These compounds include phytosterols, fatty acids, $\alpha$-pinene, citronellol, 1,8-cineole, limonene, linalool, $\alpha$-terpineol, caryophyllene oxide, sabinene, and eugenol among others [56,57]. When absorbed through the insect body surface, these compounds interfere with the basic metabolic, biochemical, physiological, and behavioral functions of the target insects. Insecticidal properties may be linked to the main phytochemicals extracted, reportedly acting alone or in synergy with others including minor constituents, thus potentiating its contact toxicity effects on weevils $[58,59]$.

Fatty acids identified by GC-MS analysis of the selected organic leaf extracts of $T$. diversifolia and $V$. lasiopus have previously been demonstrated to have insecticidal effectiveness against $S$. zeamais among other insect pests $[60,61]$. It is, therefore, not strange that the extracts killed the adult weevils in the present assay. Furthermore, the insecticidal effects of these fatty acids have been suggested to enhance the efficacy of microbial insecticides such as Bacillus thuringiensis [62].

The observed contact toxicity on weevils may be due to nonanoic acid, which is a naturally occurring saturated fatty acid also found in the studied extracts. Usually, ammonium salt, which is a form of nonanoic acid, is used as a herbicide that works by stripping the waxy cuticle of the plant, thereby causing cell disruption, cell leakage, and death of plants by desiccation. Similarly, the chemical might have stripped off the insects' cuticles causing cell leakage and eventual mortality of the weevils [63].

Major phytosterols also revealed in the GC-MS analysis of the organic leaf extracts of $T$. diversifolia and V. lasiopus can be associated with the extract toxicity effects on the weevils. Stigmasterol is among the phytosterol compounds whose accumulation in the body leads to cardiac injury and, hence, promotes mortality [64].

Para-xylene may cause death of organisms through affecting the central nervous system if swallowed or causing chemical pneumonitis when breathed into the lungs [65]. This suggests that $p$-xylene found in the organic leaf extracts of $T$. diversifolia and $V$. lasiopus could be responsible for toxicity effects of the extracts on weevils in the present study. Furthermore, previous studies have suggested that $p$-xylene could cause damage to development and reproductive systems [65].

The pesticidal effects of the selected organic leaf extracts of $T$. diversifolia and $V$. lasiopus could also be due to the presence of $\alpha$-pinene in these extracts. Benelli et al. [66] reported that $\alpha$-pinene contained in the organic leaf extract of C. sativa contributed to $98.20 \%$ insect mortality. Insecticidal properties of $\alpha$-pinene have been demonstrated against Tribolium confusum, Tribolium castaneum, Sitophilus zeamais, Callosobruchus maculatus, and Rhyzopertha dominica. Furthermore, the results of Benelli et al. [67] also indicated a similarly high mortality of $M$. persicae, also associated with the presence of $\alpha$-pinene in the organic extracts of Aulacorthum solani. 
Uptake of eugenol from the plant extracts may also have contributed to the high mortality of adult insects in this study. Eugenol has been reported to have effective toxicity effects against insects such as aphids, houseflies, and cockroaches $[68,69]$. The insecticidal activities of various plant species such as C. cinnamomum and C. cymbopogon against houseflies ( $M$. domestica) have also been largely associated with the predominance of eugenol phytochemicals in plant essential oils [69].

According to the GC-MS analysis, the organic leaf extracts of $T$. diversifolia and $V$. lasiopus contained limonene whose insecticidal activities have been extensively reported against various insects such as C. maculatus, C. subinnotatus, B. brassicae, fleas, and ticks among others [70-72]. Similarly, it is probable that the death of weevils in this study was as a result of their exposure to limonene.

The toxicity effects of these extracts could also be as a result of the presence of linalool. Insecticidal properties of linalool have been demonstrated against Sitophilus zeamais, Tribolium confusum, Tribolium castaneum, Callosobruchus maculatus, and Rhyzopertha dominica. Few reports have been published regarding the mode of action of linalool in insects. However, similar to limonene, linalool is thought to cause the death of insects by affecting the activity of nerves in insects [73-75].

The insecticidal activity of the organic leaf extracts of M. lucida has previously been attributed to sabinene among other known major components of oxygenated monoterpenes in the extract [76]. It is, therefore, likely that the toxicity effect of organic leaf extracts of $T$. diversifolia and $V$. lasiopus on adult weevils in this study was contributed by sabinene, which was also identified during phytochemical analysis of these extracts.

The toxicity of the extracts on adult weevils in the present study could also be linked to the presence of $\alpha$-bulnesene in the organic leaf extracts of $T$. diversifolia and $V$. lasiopus. According to Albuquerque et al. [77], $\alpha$-bulnesene extracted from Pogostemon cablin exhibits insecticidal activities against various urban ant species.

Additionally present in the studied extracts is caryophyllene oxide, which is an insecticidal sesquiterpene and, hence, probably responsible for the toxicity of the organic leaf extracts of $T$. diversifolia and $V$. lasiopus on weevils. According to the work in [78], sesquiterpenes such as (E)caryophyllene oxide are naturally pesticidal. Caryophyllene oxide identified in the organic extracts of Melaleuca styphelioides was found to exhibit strong insecticidal properties against Aphis spiraecola, Aphis gossypii, and M. persicae [79].

Caryophyllene in the root bark of Chinese bittersweet, Celastrus angulatus Max., was largely associated with the toxicity effects of the plant extract against insects such as Mythimna separate [78]. Furthermore, a closely similar (E)caryophyllene, myrecene, that was extracted from C. sativa, was reported to exhibit effective insect-killing potential on A. solani and M. persicae $[66,67]$. The insecticidal activity of organic leaf extracts of $T$. diversifolia and $V$. lasiopuscould be as a result of other terpenoids such as 1,8-cineole ?-terpineol, terpinen-4-ol, and linalool that were found to be highly present in the studied extracts. These are also previously reported to have insecticidal effects on insects [80-84].

As much as the extracts of $V$. lasiopus showed the presence of several insecticidal phytochemicals (terpenoids, phenolics, phytosterols, fatty acids, and alkaloids), their concentration levels were notably low to induce an effective weevil mortality in comparison to the effectiveness of T. diversifolia extracts. Therefore, that the organic leaf extracts of $V$. lasiopus had lower toxicity against maize weevils could be attributed to the presence of these potent compounds in lower concentrations than the concentrations in the organic leaf extracts of $T$. diversifolia.

The standard insecticide used in this study, Actellic, is a persistent broad-spectrum insecticide. Actellic has fumigant, stomach, and contact activity against insect pests. It is conventionally used for the control of storage pests in bulk stored grains, bagged grains, and storage surfaces. It effectively controls weevils, large grain borers, and other insects and mites on stored grains and pulses. It contains permethrin $(3 \mathrm{~g} / \mathrm{kg})$ and pirimiphos-methyl $(16 \mathrm{~g} / \mathrm{kg})$ as its active ingredients, which gives Actellic an effective control against storage pests. Pirimiphos-methyl is taken by the insect through its respiratory system and affects the pests through its fumigant and repellence effects. On the other hand, permethrin is able to penetrate the insect cuticle and, hence, effect its contact and stomach actions on pests [85].

It is worth noting that, during the 48 hours of the test observation time, the fumigant activity of EtOAc leaf extract of T. diversifolia at the highest tested extract concentration of $100 \%$ was marginally more effective $(97.47 \%$ and $91.22 \%$, respectively) than Actellic (82.47\%). This suggests a possibly better insecticidal mechanism of the extracts or mimicry of the Actellic mode of action by the active phytochemicals in the studied extracts. It is also possible that the EtOAc and DCM leaf extract of $T$. diversifolia was efficiently inhibiting alternative mechanisms for killing weevils.

The possible cause of toxicity of these extracts on weevils is through inhibition of acetylcholinesterase enzyme. Many phytochemicals affect neurotransmission and signal transduction in organisms [86]. Binding of these antagonists to acetylcholinesterase receptors causes physiological and biochemical disturbances and blockage. The subsequently observed effects include restlessness, lack of coordination, unconsciousness, and eventual death of the insect as similarly observed in the present study [86]. These observed effects as well as the rapid action of the extracts against weevils were suggested as indicative of a neurotoxic mode of action and interference of the neuromodulator (acetylcholine or octopamine) or the GABA-gated chloride channels [87].

Njoroge et al. [88] suggested that the aqueous and DCM leaf extracts of G. glauca leaves possess acetylcholinesterase enzyme inhibitory activity in Chilo partellus larvae at concentrations of $0.25,5$, and $7 \mathrm{mg} / \mathrm{mL}$ due to the presence of insecticidal phenols, terpenoids, alkaloids, and phytosteroids in the extracts. Furthermore, a study by Friedman and McDonad [89] greatly associated glycoalkaloids to the inhibition of acetylcholinesterase enzyme in beetles. Terpenoids such as 1,8-cineole, eugenol ?-pinene, ?-terpineol, 
terpinen-4-ol, camphor, and linalool are also reported to have demonstrated inhibitory effects on insects [80-84].

Nevertheless, the observed toxicity of the studied extracts on weevils could also be due to that the active constituents in these extracts targeted voltage-gated sodium channels. These channels are vital for electrical signaling in most excitable cells. Pesticidal alkaloids from sabadilla, pyrethrins, and Tanacetum cinerariae folium target these channels and bind to the specific receptors on them, hence altering their gating functions [90]. Likewise, the pesticidal phytocompounds in this study could have acted by blocking the sodium channel pores and altered their functions. This may have resulted in the cell being reexcited, inhibiting the generation of action potentials, leading to paralysis and ultimate death of the weevils [91].

Other probable mechanisms that caused the death of adult weevils in this study could include DNA intercalation, interference of protein biosynthesis, antagonistic activity of the GABA receptor chloride channel, and disruption of membrane stability in the insect by phytochemicals. There is a positive correlation between the degree of DNA intercalation and inhibition of DNA polymerase I, reverse transcriptase, and translation at the molecular level and with toxicity against insects at the organismic level [86]. Gammaaminobutyrate (GABA) is a main inhibitory neurotransmitter in both vertebrates and invertebrates. In insects, although inhibitory transmission relies mainly on gammaaminobutyrate (GABA) [87, 92, 93], unlike in mammals, GABA receptors of insects have a regulatory function not only in the central nervous system but also in the peripheral one $[87,93]$. The terpenoids present in star anise (Illicium sp.) were found to show an antagonist activity on the GABA receptor of Musca domestica [92].

\section{Conclusions}

The present study demonstrates that the organic leaf extracts of $T$. diversifolia and $V$. lasiopus have phytochemicals endowed with considerable insecticidal effects via insects' body contact toxicity on S. zeamais. The studies, hence, reveals the possible potency of the extracts in the management of the $S$. zeamais population on stored grains.

\section{Data Availability}

All data used in this study are included in this research paper.

\section{Conflicts of Interest}

The authors declare no conflicts of interest.

\section{Authors' Contributions}

S. M. Gitahi, M. P. Ngugi, D. N. Mburu, and A. K. Machocho designed the research, contributed reagents, conducted the experiments, and analyzed and interpreted the data. All authors also prepared and approved the article for publication.

\section{Acknowledgments}

The authors are grateful to the members of the animal breeding and experimentation laboratory in the Department of Biochemistry, Microbiology, and Biotechnology, Kenyatta University.

\section{References}

[1] C. O. Adedire, R. O. Akinkurolere, and O. O. Ajayi, "Susceptiblity of some maize cultivars in Nigeria to infestation and damage by maize weevil, Sitophilus zeamais (Motsch.) (Coleoptera: Curculionidae)," Nigerian Journal of Entomology, vol. 28, pp. 55-63, 2011.

[2] K. A. Vowotor, W. G. Meikle, J. N. Ayertey, and R. H. Markham, "Distribution of- and association between the larger grain borer Prostephanus truncatus (Horn) (Coleoptera: bostrichidae) and the maize weevil Sitophilus zeamais: motschulsky (Coleoptera: Curculionidae) in maize stores," Journal of Stored Products Research, vol. 31, pp. 29-36, 2005.

[3] A. A. El-Sayed, A. H. Moustafa, A. H. Hussein et al., "Potential insecticidal activity of Sarocladium strictum, an endophyte of Cynanchum acutum, against Spodoptera littoralis, a polyphagous insect pest," Biocatalysis and Agricultural Biotechnology, vol. 24, no. 10, pp. 15-24, 2020.

[4] I. Lorini and D. J. Galley, "Estimation of realized heritability of resistance to deltamethrin insecticide in selected strains of Rhyzopertha Dominica (F.) (Coleoptera: Bostrychidae)," Journal of Stored Products Research, vol. 36, no. 2, pp. 119-124, 2000.

[5] E. Nhamucho, S. Mugo, Gohole, L. Tefera, T. Kinyua, E. Mulima, Resistance of selected Mozambican local and improved maize genotypes to maize weevil, Sitophilus zeamais (Motschulsky)," Journal of Stored Products Research, vol. 73, pp. 115-124, 2017.

[6] G. M. W. Lengai, J. W. Muthomi, and E. R. Mbega, "Phytochemical activity and role of botanical pesticides in pest management for sustainable agricultural crop production," Scientific African, vol. 7, pp. 2-39, 2020.

[7] I. Kivimägi, A. Kuusik, A. Ploomi et al., "Gas exchange patterns in Platynus assimilis (Coleoptera: carabidae): respiratory failure induced by a pyrethroid," European Journal of Entomology, vol. 110, no. 1, pp. 47-54, 2013.

[8] R. Karise, R. Muljar, G. Smagghe et al., "Sublethal effects of kaolin and the biopesticides Prestop-Mix and BotaniGard on metabolic rate, water loss and longevity in bumble bees (Bombus terrestris)," Journal of Pest Science, vol. 2, pp. 40-49, 2015.

[9] C. Regnault-Roger and B. J. R. Philogène, "Past and current prospects for the use of botanicals and plant allelochemicals in integrated pest management," Pharmaceutical Biology, vol. 46, no. 1-2, pp. 41-52, 2008.

[10] S. Chowański, Z. Adamski, P. Marciniak et al., "A review of bioinsecticidal activity of solanaceae alkaloids," Toxins, vol. 8 , no. 3, p. 60, 2016.

[11] V. Sivasrini, "Evaluation of indigenous products and boric acid against storedgrain pests," Thesis, University of Agricultural Sciences, Bengaluru, India, 2001.

[12] C. Newman, "Grain storage: maintaining grain quality," Department of Agriculture and Food, vol. 1, no. 4, pp. 129-134, 2008.

[13] O. O. Longe and T. I. Ofuya, "Ecology, life cycle and ways of subjugating the maize weevil Sitophilus zeamais in storage," 
International Journal of Agriculture and Environmental Research, vol. 2, no. 2, pp. 298-313, 2016.

[14] P. W. C. Green, S. R. Belmain, P. A. Ndakidemi, I. W. Farrell, and P. C. Stevenson, "Insecticidal activity of Tithonia diversifolia and Vernonia amygdalina," Industrial Crops and Products, vol. 110, pp. 15-21, 2017.

[15] W. Linthoingambi and S. S. Mutum, "Antimicrobial activities of different solvent extracts of Tithonia diversifolia (Hemsely) A. Gray," Asian Journal of Plant Science \& Research, vol. 3, no. 5, pp. 50-54, 2013.

[16] W. A. Adeyemi and A. A. Osipitan, "Evaluation of the effectiveness of propolis and garlic in the management of maize weevil (Sitophilus zeamais) in stored maize (Zea mays) grains," Munis Entomology and Zoology, vol. 9, no. 1, pp. 117-124, 2014.

[17] B. N. Irungu, G. M. Rukunga, G. M. Mungai, and C. N. Muthaura, "In vitro antiplasmodial and cytotoxicity activities of 14 medicinal plants from Kenya," South African Journal of Botany, vol. 73, no. 2, pp. 204-207, 2007.

[18] F. W. Muregi, A. Ishih, T. Miyase et al., "Antimalarial activity of methanolic extracts from plants used in Kenyan ethnomedicine and their interactions with chloroquine (CQ) against a CQ-tolerant rodent parasite, in mice," Journal of Ethnopharmacology, vol. 111, no. 1, pp. 190-195, 2007.

[19] W. Wanzala, "Potential of traditional knowledge of plants in the management of arthropods in livestock industry with focus on (Acari) ticks," Evidence-based Complementary and Alternative Medicine, vol. 10, pp. 11-55, 2017.

[20] A. Onekutu, L. C. Nwosu, and R. E. Abakpa, "Comparative efficacy of aqueous extracts of Tithonia diversifolia [asteraceae] and Vernonia amygdalina [asteraceae] leaves in the management of Sitophilus zeamais infestation in stored maize," Journal of Pharmacy and Biological Sciences, vol. 10, no. 3, pp. 66-70, 2015.

[21] C. O. Adedire and J. O. Akinneye, "Biological activity of tree marigold, Tithonia diversifolia, on cowpea seed bruchid, Callosobruchus maculatus (Coleoptera: bruchidae)," Annals of Applied Biology, vol. 144, no. 2, pp. 185-189, 2004.

[22] J. N. Mwangi, H. S. Ozwara, and M. M. Gicheru, "Epidemiology of tunga penetrans infestation in selected areas in Kiharu constituency, Murang'a County, Kenya," Tropical diseases, travel medicine and vaccines, vol. 1, no. 1, pp. 13-15, 2015.

[23] J. M. Githinji, T. Maitho, and J. M. Mbaria, “Antifleas activity and safety of tithoniadiversifolia and sennadidymobotrya extracts," Journal of Pharmacy and Pharmacology Research, vol. 2, pp. 78-92, 2018.

[24] P. G. Kareru, A. N. Gachanja, J. M. Keriko, and G. M. Kenji, "Antimicrobial activity of some medicinal plants used by herbalists in eastern province, Kenya," African Journal of Traditional, Complementary and Alternative Medicines, vol. 5, no. 1, pp. 51-55, 2008.

[25] R. K. Singh and A. K. Singh, "Efficacy of different indigenous plant products as grain protectants against Rhyzopertha Dominica (Fab) on wheat," Indian Journal of Entomology, vol. 67, pp. 196-198, 2005.

[26] P. Tiwari, M. Kumar, M. Kaur, G. Kaur, and H. Kaur, "Phytochemical screening and extraction: a review," Internationale Pharmacentia Science, vol. 1, pp. 98-106, 2011.

[27] S. D. Deshmukh and M. N. Borie, "Studies on the insecticidal properties of indigenous plant products," Indian Journal of Entomology, vol. 37, pp. 11-18, 1975.

[28] M. A. Sulherie, P. Golob, B. M. D. Tran, and G. Farrell, "The effect of attributes of Vigna spp. on the bionomics of
Callosobruchus maculatus," Entomologia Experimentalis et Applicata, vol. 106, pp. 159-168, 2003.

[29] J. A. Ojo and A. A. Omoloye, "Rearing the maize Weevil,Sitophilus zeamais, on an artificial maize-cassava diet," Journal of Insect Science, vol. 12, no. 69, pp. 1-9, 2012.

[30] S. A. Dar, A. R. Yousuf, F. A. Ganai, P. Sharma, N. Kumar, and R. Singh, "Bioassay guided isolation and identification of antiinflammatory and anti-microbial compounds from Urtica dioica L. (Urticaceae) leaves," African Journal of Biotechnology, vol. 11, pp. 12910-12920, 2012.

[31] K. D. Ileke and D. S. Bulus, "Response of lesser grain borer, Rhizopertha Dominica (Fabr.) [Coleoptera: bostrichidae] to powders and extracts of Azadirachta 87 indica and Piper guineense seeds," Jordan Journal of Biological Sciences, vol. 5, no. 5, pp. 315-320, 2012.

[32] W. S. Abbott, "A method of computing the effectiveness of an insecticide," Journal of Economic Entomology, vol. 18, no. 2, pp. 265-267, 1925.

[33] R. K. Upadhyay and S. Ahmad, "Management strategies for control of stored grain insect pests in farmer stores and public warehouses, Review article," World Journal of Agricultural Sciences, vol. 7, no. 5, pp. 549-2011, 2011.

[34] C. Ikbal and R. Pavela, "Essential oils as active ingredients of botanical insecticides against aphids," Journal of Pest Science, vol. 7, pp. 1-16, 2019.

[35] S. Malik, P. Chaurasia, S. Lahudkar, B. Uprety, and S. R. Bhaumik, "Rad26p regulates the occupancy of histone $\mathrm{H} 2 \mathrm{~A}-\mathrm{H} 2 \mathrm{~B}$ dimer at the active genes in vivo," Nucleic Acids Research, vol. 40, no. 8, pp. 3348-3363, 2012.

[36] G. Stoll, "Natural crop protection in the tropics," Letting Information Come to Life E and T, Mullerbader Fildstadt Publishers, Filderstadt, Germany, 2001.

[37] J. C. Oyedokun, F. A. Anikwe, and I. U. Okelana, "Mokwunye and O. M. Azeez Pesticidal efficacy of three tropical herbal plants' leaf extracts against Macrotermes bellicosus, an emerging pest of cocoa, Theobroma cacao L," Journal of Biopesticides, vol. 4, no. 2, pp. 131-137, 2011.

[38] A. Trivedi, N. Nayak, and J. Kumar, "Fumigant toxicity study of different essential oils against stored grain pest Callosobruchus chinensis," Journal of Pharmacognosy and Phytochemistry, vol. 6, no. 4, pp. 1708-1711, 2017.

[39] R. O. Ouko, S. C. Koech, W. M. Arika et al., "Bioefficacy of organic extracts of A. sativum against S. zeamais(Coleoptera; Dryophthoridae)," Biological Systems, vol. 6, p. 174, 2017.

[40] M. Ong, N. Chomistek, H. Dayment, W. Goerzen, and D. Baines, "Insecticidal activity of plant powders against the parasitoid, pteromalus venustus, and its host, the alfalfa leafcutting bee," Insects, vol. 11, no. 6, p. 359, 2020.

[41] K. A. Sedy and E. H. Koschier, "Bioactivity of carvacrol and thymol against Frankliniella occidentalis and Thrips tabaci," Journal of Applied Entomology, vol. 127, no. 6, pp. 313-316, 2003.

[42] M. Negahban, S. Moharramipour, and F. Sefidkon, "Fumigant toxicity of essential oil from Artemisia sieberi Besser against three stored-product insects," Journal of Stored Products Research, vol. 43, no. 2, pp. 123-128, 2007.

[43] A. Ayvaz, S. Karaborklu, and O. Sagdic, "Fumigant toxicity of five essential oils against the eggs of Ephestia kuehniella Zeller and Plodia interpunctella (Hübner) (Lepidoptera: Pyralidae)," Asian Journal of Chemistry, vol. 21, pp. 596-604, 2009.

[44] A. Ayvaz, O. Sagdic, S. Karaborklu, and I. Ozturk, "Insecticidal activity of the essential oils from different plants against three stored-product insects," Journal of Insect Science, vol. 10, no. 21, pp. 1-13, 2010. 
[45] S. Karabörklü, A. Ayvaz, and S. Yilmaz, "Bioactivities of different essential oils against the adults of two stored product insects," Pakistan Journal of Zoology, vol. 42, pp. 679-686, 2010.

[46] S. Karabörklü, A. Ayvaz, S. Yilmaz, and M. Akbulut, "Chemical composition and fumigant toxicity of some essential oils against Ephestia kuehniella," Journal of Economic Entomology, vol. 104, no. 4, pp. 1212-1219, 2011.

[47] U. Zeynep, K. Salih, C. Menderes, Ö. Bintug, and B. Mehmet, "Chemical composition, antibacterial and insecticidal activities of the essential oil from the pistacia terebinthus L. Spp. Palaestina (boiss.) (anacardiaceae)," Journal of Food Processing and Preservation, vol. 17, pp. 45-49, 2012.

[48] A. Maqsood, P. Qin, G. Zumin et al., "Insecticidal activity and biochemical composition of Citrullus colocynthis, Cannabis indica and Artemisia argyi extracts against cabbage aphid (Brevicoryne brassicae L.)," Scientific Reports Nature research, vol. 10, p. 522, 2020.

[49] W.-I. Choi, E.-H. Lee, B.-R. Choi, H.-M. Park, and Y.-J. Ahn, "Toxicity of plant essential oils to Trialeurodes vaporariorum (Homoptera: aleyrodidae)," Journal of Economic Entomology, vol. 96, no. 5, pp. 1479-1484, 2003.

[50] M. K. Chaubey, "Acute, Lethal and synergistic effects of some terpenes against Tribolium castaneum Herbst (Coleoptera: tenebrionidae)," Ecological Balkanica, vol. 4, no. 1, pp. 53-62, 2012.

[51] J. Dai and R. J. Mumper, "Plant phenolics: extraction, analysis and their antioxidant and anticancer properties," Molecules, vol. 15, no. 10, pp. 7313-7352, 2010.

[52] M. Dehkharghanian, H. Adenier, and M. A. Vijayalakshmi, "Study of flavonoids in aqueous spinach extract using positive electrospray ionisation tandem quadrupole mass spectrometry," Food Chemistry, vol. 121, no. 3, pp. 863-870, 2010.

[53] M. M. Cowan, "Plant products as antimicrobial agents," Clinical Microbiology Reviews, vol. 12, no. 4, pp. 564-582, 1999.

[54] P. J. Houghton and A. Raman, "Important concepts," Laboratory Handbook for the Fractionation of Natural Extracts, Chapman \& Hall, New York, NY, USA, 1998.

[55] H.-Y. Lin, Y.-H. Kuo, Y.-L. Lin, and W. Chiang, "Antioxidative effect and active components from leaves of Lotus (Nelumbo nucifera)," Journal of Agricultural and Food Chemistry, vol. 57, no. 15, pp. 6623-6629, 2009.

[56] R. V. Lalla, L. L. Patton, and A. Dongari-Bagtzoglou, "Oral candidiasis: pathogenesis, clinical presentation, diagnosis and treatment strategies," Journal of the California Dental Association, vol. 41, pp. 263-268, 2013.

[57] A. Lucia, A. C. Toloza, E. Guzmán, F. Ortega, and R. G. Rubio, "Novel polymeric micelles for insect pest control: encapsulation of essential oil monoterpenes inside a triblock copolymer shell for head lice control," Peer Journal, vol. 20, no. 5, pp. 31-71, 2017.

[58] M. O. Omolo, D. Okinyo, I. O. Ndiege, W. Lwande, and A. Hassanali, "Repellency of essential oils of some Kenyan plants against Anopheles gambiae," Phytochemistry, vol. 65, no. 20, pp. 2797-2802, 2004.

[59] C. H. Liu, A. K. Mishra, R. X. Tan, C. Tang, H. Yang, and Y. F. Shen, "Repellent and insecticidal activities of essential oils from Artemisia princeps and Cinnamomum camphora and their effect on seed germination of wheat and broad bean," Bioresource Technology, vol. 97, no. 15, pp. 1969-1973, 2006.

[60] B.-H. Lee, S.-E. Lee, P. C. Annis, S. J. Pratt, B.-S. Park, and F. Tumaalii, "Fumigant toxicity of essential oils and
Monoterpenes against the red flour beetle, Tribolium castaneum Herbst," Journal of Asia-Pacific Entomology, vol. 5, no. 2, pp. 237-240, 2002.

[61] M.-Y. Lee, M.-H. Liao, Y.-N. Tsai, K.-H. Chiu, and H.-C. Wen, "Identification and anti-human glioblastoma activity of tagitinin C from Tithonia diversifolia methanolic extract," Journal of Agricultural and Food Chemistry, vol. 59, no. 6, pp. 2347-2355, 2011.

[62] E. Konecka, J. Baranek, A. Hrycak, and A. Kaznowski, "Insecticidal activity of Bacillus thuringiensis strains isolated from soil and water," Science World Journal, vol. 5, no. 1, pp. 62-91, 2012.

[63] P. E. Månsson, "Host selection and antifeedants in Hylobius abietis pine weevils," Doctoral Thesis, Swedish University of Agricultural Sciences Alnarp, Uppsala, Swedish, 2005.

[64] L. Tao, S. Ozarkar, J. M. Beck, and V. Bhandawat, "Statistical structure of locomotion and its modulation by odors," eLife, vol. 8, no. 4, pp. 12-35, 2019.

[65] National Institute for Occupational Safety and Health (NIOSH), "Guidelines for safe handling of hazardous drugs: a systematic review," PLoS One, vol. 13, no. 5, 2018.

[66] G. Benelli, R. Pavela, R. Petrelli et al., "The essential oil from industrial hemp (Cannabis sativa L.) by-products as an effective tool for insect pest management in organic crops," Industrial Crops and Products, vol. 122, pp. 308-315, 2018.

[67] G. Benelli, R. Pavela, A. Canale, and H. Mehlhorn, "Tick repellents and acaricides of botanical origin: a green roadmap to control tick-borne diseases?" Parasitology Research, vol. 115, no. 7, pp. 2545-2560, 2016.

[68] J. H. Ping, "Pest treatment composition," US Patent number 7282211, 2007.

[69] S. Radhika, S. K. Kosmulalage, and S. W. Indira, "Insecticidal activity of essential oils of ceylon cinnamomum and cymbopogon species against," Musca domestica, vol. 7, no. 4, pp. 352-354, 2011.

[70] W. S. Nyamador, G. K. Ketoh, K. Amévoin, Y. Nuto, H. K. Koumaglo, and I. A. Glitho, "Variation in the susceptibility of two Callosobruchus species to essential oils," Journal of Stored Products Research, vol. 46, no. 1, pp. 48-51, 2010.

[71] M. B. Isman, S. Miresmailli, and C. Machial, "Commercial opportunities for pesticides based on plant essential oils in agriculture, industry and consumer products," Phytochemistry Reviews, vol. 10, no. 2, pp. 197-204, 2011.

[72] F. Jahan, H. Abbasipour, and G. Hasanshahi, "Fumigant toxicity and nymph production deterrence effect of five essential oils on adults of the cabbage Aphid, Brevicoryne brassicaeL. (Hemiptera: aphididae)," Journal of Essential Oil Bearing Plants, vol. 19, no. 1, pp. 140-147, 2016.

[73] S. A. M. Abdelgaleil and A. F. El-aswad, "Molluscicidal and antifeedant activities of diterpenes from Euphorbia paralias L," Pest Management Science, vol. 58, pp. 479-482, 2005.

[74] S. A. M. Abdelgaleil, M. I. E. Mohamed, M. E. I. Badawy, and S. A. A. El-arami, "Fumigant and contact toxicities of monoterpenes to Sitophilus oryzae (L.) and Tribolium castaneum (herbst) and their inhibitory effects on acetylcholinesterase activity," Journal of Chemical Ecology, vol. 35, no. 5, pp. 518-525, 2009.

[75] R. S. Rattan, "Mechanism of action of insecticidal secondary metabolites of plant origin," Crop Protection, vol. 29, no. 9, pp. 913-920, 2010.

[76] K. A. Hammer, C. F. Carson, and T. V. Riley, "Effects of Melaleuca alternifolia (tea tree) essential oil and the major monoterpene component terpinen-4-ol on the development 
of single- and multistep antibiotic resistance and antimicrobial susceptibility," Antimicrobial Agents and Chemotherapy, vol. 56, no. 2, pp. 909-915, 2012.

[77] M. R. J. R. Albuquerque, T. L. G. Lemos, O. D. L. Pessoa, E. P. Nunes, R. F. Nascimento, and E. R. Silveira, "Chemical composition of the essential oil fromVernonia scorpioides (Asteraceae)," Flavour and Fragrance Journal, vol. 22, no. 4, pp. 249-250, 2007.

[78] W.-J. Zhang, C.-X. You, K. Yang et al., "Bioactivity of Essential Oil of Artemisia argyi Lévl. et Van. and Its Main Compounds Against Lasioderma serricorne," Journal of Oleo Science, vol. 63, no. 8, pp. 829-837, 2014.

[79] B. W. Amoabeng, G. M. Gurr, C. W. Gitau, H. I. Nicol, L. Munyakazi, and P. C. Stevenson, "Tri-trophic insecticidal effects of African plants against cabbage pests," PLoS One, vol. 8, no. 11, pp. e78651-e78613, 2013.

[80] S. Savelev, E. Okello, N. S. L. Perry, R. M. Wilkins, and E. K. Perry, "Synergistic and antagonistic interactions of anticholinesterase terpenoids in Salvia lavandulaefolia essential oil," Pharmacology Biochemistry and Behavior, vol. 75, no. 3, pp. 661-668, 2003.

[81] M. Miyazawa and C. Yamafuji, "Inhibition of acetylcholinesterase activity by bicyclic monoterpenoids," Journal of Agricultural and Food Chemistry, vol. 53, no. 5, pp. 1765-1768, 2005.

[82] M. Miyazawa and C. Yamafuji, "Inhibition of acetylcholinesterase activity by tea tree oil and constituent terpenoids," Flavour and Fragrance Journal, vol. 21, no. 2, pp. 198-201, 2006.

[83] M. I. Picollo, A. C. Toloza, G. Mougabure Cueto, J. Zygadlo, and E. Zerba, "Anticholinesterase and pediculicidal activities of monoterpenoids," Fitoterapia, vol. 79, no. 4, pp. 271-278, 2008.

[84] M. D. López and M. J. Pascual-Villalobos, "Mode of inhibition of acetylcholinesterase by monoterpenoids and implications for pest control," Industrial Crops and Products, vol. 31, no. 2, pp. 284-288, 2010.

[85] R. W. D. Taylor, "Phosphine a major fumigant at risk," Journal of International Pest Control, vol. 31, pp. 10-14, 1989.

[86] M. Wink, T. Schmeller, and B. Latz-Brüning, "Mode of action of allelochemicals alkaloids: interaction with neuroreceptors, DNA and other molecular targets," Journal of Chemical Ecology, vol. 24, no. 11, pp. 1881-1937, 1998.

[87] A. K. El Hassani, J. P. Dupuis, M. Gauthier, and C. Armengaud, "Glutamatergic and GABAergic effects of fipronil on olfactory learning and memory in the honeybee," Invertebrate Neuroscience, vol. 9, no. 2, pp. 91-100, 2009.

[88] W. A. Njoroge, M. P. Ngugi, U. Aliyu et al., "In vitro antiacetylcholinesterase activity of dichloromethane leaf extracts of carphalea glaucescens in chilo partellus larvae," Biochemistry \& Analytical Biochemistry, vol. 5, no. 2, p. 264, 2016.

[89] M. Friedman, G. M. McDonald, and M. Filadelfi-Keszi, "Potato glycoalkaloids: chemistry, analysis, safety, and plant physiology," Critical Reviews in Plant Sciences, vol. 16, no. 1, pp. 55-132, 2010.

[90] K. S. Silver, Y. Du, Y. Nomura et al., "Voltage-gated sodium channels as insecticide targets," Advances in Insect Physiology, vol. 46, pp. 389-433, 2014.

[91] V. L. Salgado, "Insecticide mode of action: technical training manual," BASF Corporation, Ludwigshafen, Germany, 2013.

[92] T. J. Schmidt, M. Gurrath, and Y. Ozoe, "Structure-activity relationships of seco-prezizaane and picrotoxane/picrodendrane terpenoids by Quasar receptor-surface modeling,"
Bioorganic \& Medicinal Chemistry, vol. 12, no. 15, pp. 41594167, 2004.

[93] S. D. Buckingham, P. C. Biggin, B. M. Sattelle, L. A. Brown, and D. B. Sattelle, "Insect GABA receptors: splicing, editing, and targeting by antiparasitics and insecticides," Molecular Pharmacology, vol. 68, no. 4, pp. 942-951, 2005. 